\title{
Integrin characterization in pulmonary bronchioles
}

\author{
Renald A. Blundell ${ }^{\mathrm{a}, \mathrm{b}, *}$, David J. Harrison ${ }^{\mathrm{b}}$ \\ ${ }^{a}$ Department of Physiology and Biochemistry, University of Malta, Msida MSD06, Malta \\ ${ }^{\mathrm{b}}$ Department of Pathology, University of Edinburgh Medical School, Edinburgh EH8 9AG, Scotland
}

Received 1 April 2005

Available online 6 June 2005

\begin{abstract}
Integrins are a family of cell surface glycoproteins that act as receptors for ECM proteins or for membrane bound counter-receptors on other cells. The integrin receptor family of vertebrates includes at least 16 distinct $\alpha$ subunits and at least $8 \beta$ subunits which can associate to form more than 20 distinct integrins. So far, there are no published reports describing integrin characterization in mouse lung tissue and mouse Clara cells. This paper described the characterization of six integrins, mainly $\alpha_{5}, \alpha_{v}, \alpha_{6}, \beta_{1}, \beta_{3}$, and $\beta_{4}$, in mouse pulmonary bronchioles and also in Clara cell cultures. $\alpha_{5}, \alpha_{v}, \alpha_{6}, \beta_{1}$, and $\beta_{4}$ integrins were present in Clara cells both in tissue sections and cultures. $\beta_{3}$ integrin was found to be absent in mouse Clara cells.
\end{abstract}

(C) 2005 Elsevier Inc. All rights reserved.

Keywords: Clara cells; Integrin; Pulmonary bronchioles

\section{Introduction}

Integrins are a family of cell surface glycoproteins that act as receptors for ECM proteins or for membrane bound counter-receptors on other cells. Integrin mediated cellECM adhesion sites are complex specialized structures termed focal contact or focal adhesions (Aplin et al., 1998). Each integrin is a heterodimer that contains an $\alpha$ and a $\beta$ subunit with each subunit having a large extracellular domain, a single membrane spanning region, and in most cases (other than $\beta_{4}$ ), a short cytoplasmic domain (Frisch and Ruoslahti, 1997; Hynes, 1992, 2000). The integrin receptor family of vertebrates includes at least 16 distinct $\alpha$ subunits and at least $8 \beta$ subunits which can associate to form more than 20 distinct integrins (Coraux et al., 1998; Frisch and Ruoslahti, 1997; Hynes, 1992; Ingber, 1991; Liapis and Hutton, 1997; Mizejewski, 1999; Schwartz, 1997).

The integrins expressed in diverse cell types display different ligand specificities. In addition, during dynamic and

\footnotetext{
* Corresponding author.

E-mail address: renald.blundell@um.edu.mt (R.A. Blundell).
}

complex processes, such as organ development and tumor progression and metastasis, the cellular distribution and/or intensity of expression may change (Arroyo et al., 2000; Boudreau and Jones, 1999; Brown, 2000; Coraux et al., 1998; Dedhar and Hannigan, 1996; Felding-Habermann et al., 2001; Frisch and Ruoslahti, 1997; Giancotti, 1997; Hemler, 1998; Howe et al., 1998; Hynes, 1992; Ingber, 1991; Legier et al., 2001; Schwartz, 1997; Shyy and Chien, 1997).

There are no published reports describing integrin characterization in mouse lung tissue and mouse Clara cells. Six integrins were investigated: $\alpha_{5}, \alpha_{v}, \alpha_{6}, \beta_{1}, \beta_{3}$, and $\beta_{4}$.

\section{Materials and methods}

\section{Isolation and culturing of mouse bronchiolar cells}

Clara cells were isolated using a modification of methods described previously (Belinksy et al., 1995; Masek and Richards, 1990; Oreffo et al., 1990; Richards et al., 1990; Van Scott et al., 1987).

In brief, mice $(\mathrm{C} 3 \mathrm{H} / \mathrm{HE}$ strain or p21 ko mice either male or female, between 4 to 8 weeks old) were sacrificed by lethal intraperitoneal injection of $0.5 \mathrm{ml}$ pentabarbitone 
(Sagatal ${ }^{\mathrm{TM}}$ ). The ventral surface skin was removed, and a midline incision was made to allow entry into the peritoneal cavity. The gastrointestinal tract was displaced to the right and the major dorsal blood vessels cut. The position of the trachea was located, and a cannula $(1 \mathrm{~mm}$ Luer cannula, CAN1004, Scientific Lab. Supplies) was inserted from a partial cut at the top of the trachea. The diaphragm was carefully opened by a small incision just below the xiphisternum followed by widening this cut in both directions. The rib cage was removed, and care was taken not to puncture the lungs. A portion of the thymus was removed for easier access to the vessels around the heart.

The lower region of the heart was gripped with a hemostat, and a cannula (1.7 mm Luer cannula, CAN1008, Scientific Lab. Supplies) was inserted into the pulmonary artery through an incision in the pericardium. Sterile saline $(0.15 \mathrm{M} \mathrm{NaCl})$ was gravity fed through the cannula, causing an increase in size of the left atrium. An incision was made in the left atrium to allow fluid exit. Lungs were artificially ventilated with a $1.0 \mathrm{ml}$ syringe of air. After 3 ventilations, the lungs were totally free of blood and appeared completely white. The heart was detached and discarded.

A syringe containing preheated trypsin at $37^{\circ} \mathrm{C}$ was attached to the cannula, and trypsin (T8003, Sigma) was intratracheally instilled. The lungs were detached at the bottom by cutting the esophagus, the posterior vena cava, and any strands of tissue holding them to the diaphragm, and then the whole preparation was turned around so as to work from the top of the trachea. The lung was freed and removed intact from the cavity. The lung was cleaned from any remains of esophagus and any other debris. The lung was transferred into a vial containing preheated phosphate buffer saline (PBS) at $37^{\circ} \mathrm{C}$ and incubated for $15 \mathrm{~min}$ at $37^{\circ} \mathrm{C}$.

From the point onwards, the isolation was carried out in a sterile laminar flow tissue culture hood (Class II) using aseptic techniques and sterile solutions. Digested lungs from 8 mice were place in a sterile plastic petri dish and chopped with sterile scissors to small pieces of about $1 \mathrm{~mm}$. Fetal bovine serum ( $2 \mathrm{ml} /$ lungs) was added to the minced lungs to inhibit further trypsin activity. The minced lungs were transferred to a $50 \mathrm{ml}$ centrifuge tube, and DNase I solution ( $3 \mathrm{ml} / \mathrm{lungs})$ was added. Treatment of DNase I reduce viscosity. The mixture was hand shaken for $4 \mathrm{~min}$. The suspension was filtered through $150 \mu$ and $30 \mu$ nylon filters and topped-up to $50 \mathrm{ml}$ with DNase 2 solution. The tube was centrifuged at low speed of $32 \mathrm{~g}$ at $10^{\circ} \mathrm{C}$ for $6 \mathrm{~min}$ in order to obtain functionally active Clara cells. The supernatant was removed, and $50 \mathrm{ml}$ of DNase 2 solution was added to the pellet at the bottom of the tube. The tube was hand shaken for $1 \mathrm{~min}$ and centrifuged at $32 \mathrm{~g}$ at $10^{\circ} \mathrm{C}$ for $6 \mathrm{~min}$.

The supernatant was removed, and $10 \mathrm{ml}$ medium (1:1 M199/HamF12, 1\% glutamine, 1\% streptomycin) was added and hand shaken for $1 \mathrm{~min}$. At this point, the isolation consists predominantly of bronchiolar cells, macrophages, and fibroblasts. The latter two cell types have an increased capacity for adherence than epithelial bronchiolar cells. The suspension was transferred to a sterile non-tissue culture petri dish and incubated at $37^{\circ} \mathrm{C}$ for $2 \mathrm{~h}$ at $5 \% \mathrm{CO}_{2}$ in air to allow differential attachment.

The suspension was transferred to a $50 \mathrm{ml}$ centrifuge tube and centrifuged at $100 \times g$ for $5 \mathrm{~min}$ at $10^{\circ} \mathrm{C}$. The supernatant was removed, and an appropriate culture medium (1:1 mixture of Hams F12 (Gibco) and M-199 medium (Gibco) supplemented with $2 \mathrm{mM}$ L-glutamine, $10 \mu \mathrm{g} / \mathrm{ml}$ insulin, $5 \mu \mathrm{g} / \mathrm{ml}$ transferrin, $100 \mathrm{ng} / \mathrm{ml}$ hydrocortisone, $10 \mathrm{ng} / \mathrm{ml} \mathrm{EGF}, 0.1 \mathrm{ng} / \mathrm{ml}$ retinyl acetate, and Pen/Strep. (Belinksy et al., 1995; Masek and Richards, 1990; Van Scott et al., 1987; Van Winkle et al., 1996) was added to an approximately $1 \times 10^{4}$ clumps $/ \mathrm{ml}$. $50 \mu \mathrm{l}$ aliquots were taken for an approximate cell count.

Cells were counted using a hemocytometer. However, this apparatus is designed primarily for quantification of single cell suspension. Isolated Clara cells are usually in clumps and with typical 'bunch of grapes' morphology. Thus, for cell estimation, the number of clumps and individual cells were recorded and an estimate made of total cell number.

Once isolated, cells were plated onto 16-well glass chamber slides (Gibco) which had been pre-coated with $50 \mu \mathrm{g} / \mathrm{ml}$ fibronectin and incubated at $37^{\circ} \mathrm{C}, 5 \% \mathrm{CO}_{2}$ in air. Cells were allowed to attach overnight after which the medium was replaced to remove dead and unattached cells. Medium was subsequently replaced every 2 days.

Cells were fixed at time 24,72 , and $120 \mathrm{~h}$ by methanol or methocarn $(100 \mathrm{ml}$ methanol; $50 \mathrm{ml}$ chloroform; $25 \mathrm{ml}$ glacial acetic acid) at $-20^{\circ} \mathrm{C}$.

\section{Lung tissue sections}

Lung tissues were fixed in buffered formalin for $16 \mathrm{~h}$ and then processed to paraffin wax in a vacuum impregnating processor. Paraffin embedded sections were cut on a microtone to a thickness of $3 \mu \mathrm{m}$.

Paraffin tissue sections were place in xylene for $15 \mathrm{~min}$. The sections were then transferred in a series of alcohol gradients from $100 \%$ to $74 \%$ to $64 \%$ and then tap water for $10 \mathrm{~min}$ each.

Antigen retrieval. Two methods of antigen retrieval were used: trypsin antigen retrieval and microwave antigen retrieval.

a. Trypsin antigen retrieval. A glass slide container was prewarmed in $37^{\circ} \mathrm{C}$ incubator. Trypsin solution $(100$ $\mathrm{mg}$ trypsin, $100 \mathrm{mg}$ calcium chloride, $100 \mathrm{ml} \mathrm{H}_{2} \mathrm{O}$, adjusted to $\mathrm{pH} 7.6$ using $0.2 \mathrm{M}$ Tris) was prewarmed for 5-10 $\mathrm{min}$ in a $37^{\circ} \mathrm{C}$ in a water bath. Slides that were de-waxed and rehydrated (as described above) were placed in glass slide container containing the pre-warmed trypsin for $30 \mathrm{~min}$ at 
Table 1

Integrin characterization

\begin{tabular}{lllllll}
\hline & $\alpha_{6}$ & $\alpha_{5}$ & $\alpha_{\mathrm{v}}$ & $\beta_{1}$ & $\beta_{3}$ & $\beta_{4}$ \\
\hline Tissue sections & ++ & ++++ & +++ & +++ & 0 & ++++ \\
$24 \mathrm{~h}$ & ++ & ++++ & +++ & +++ & 0 & ++++ \\
$72 \mathrm{~h}$ & + & +++ & +++ & +++ & 0 & ++++ \\
$120 \mathrm{~h}$ & + & ++++ & +++ & +++ & 0 & ++++ \\
\hline
\end{tabular}

Key: ++++ , very strong positive. +++ , strong positive. ++ , moderately positive. + , weak positive. \pm , very weak positive. 0 , no stain.

$37^{\circ} \mathrm{C}$. Then, slides were rinsed with $\mathrm{H}_{2} \mathrm{O}$ and equilibrated in Tris-buffered saline (TBS).

b. Microwave antigen retrieval. DAKO antigen retrieval solution was prepared by dilution 1:100 with distilled water. A microwave dish was filled up with antigen retrieval solution and preheated in a microwave to boiling point. Slides that were de-waxed and rehydrated (as described above) were placed in a plastic slide rack and placed in a microwave dish containing the preheated antigen retrieval solution and were microwaved three times for 5 min each. The slides were allowed to cool for 30 min and then were rinsed with $\mathrm{H}_{2} \mathrm{O}$ and equilibrated in TBS.

\section{Immunohisto/cytochemistry studies}

Most of the antibodies, mainly $\alpha_{5}, \alpha_{v}, \alpha_{6}, \beta_{1}$, and $\beta_{3}$, were obtained as a gift from Prof. Hideo Yagita, Department of Immunology, Juntendo University School of Medicine, Tokyo, Japan, while $\beta_{4}$ antibody was commercially available from Chemicon. The $\beta_{1}$ antibody obtained from Prof.
Yagita is now commercially available from PharMingen (Catalogue No. 553837), and this is a functional $\beta_{1}$ blocking antibody (Burns et al., 2001; Noto et al., 1995). $\beta_{4}$ antibody (AB1922, Chemicon) was used at a concentration of $1 / 100$, while $\alpha_{5}, \alpha_{v}, \alpha_{6}, \beta_{1}$, and $\beta_{3}$ antibodies were used at a concentration of $1 / 10$.

Slides were equilibrated in TBS for $5 \mathrm{~min}$. The slides were blocked with an appropriate serum in which the secondary antibody had been raised. Primary antibody at a concentration specified in the Table 1 was applied for $2 \mathrm{~h}$ followed by three $5 \mathrm{~min}$ washes with Tris-buffered saline Tween-20 (TBST). Secondary antibody was put on for 30 min then washed three times for 5 min each with TBST and then visualized using the $\mathrm{ABC}$ kit. For immunofluorescence, a secondary antibody conjugated to an Alexa $^{\mathrm{TM}}$ dye was used as described below. A negative control was carried out by using TBS instead of the primary antibody.

After the primary antibodies, the slides were washed three times of $5 \mathrm{~min}$ each with TBST. An Alexa ${ }^{\mathrm{TM}}$ conjugated secondary antibody (diluted 1:200 in serum) was put on the slide and incubated for $3 \mathrm{~min}$. The slides were then washed three times for 5 min each and mounted using DAKO fluorescent mounting medium. The slides were then visualized using either a ultraviolet (UV) microscope or confocal microscope.

Cell counting. In a wide range of variation, the degree of immunocyto/histochemical staining was observed. Thus, strongly stained cells were considered as positive staining,
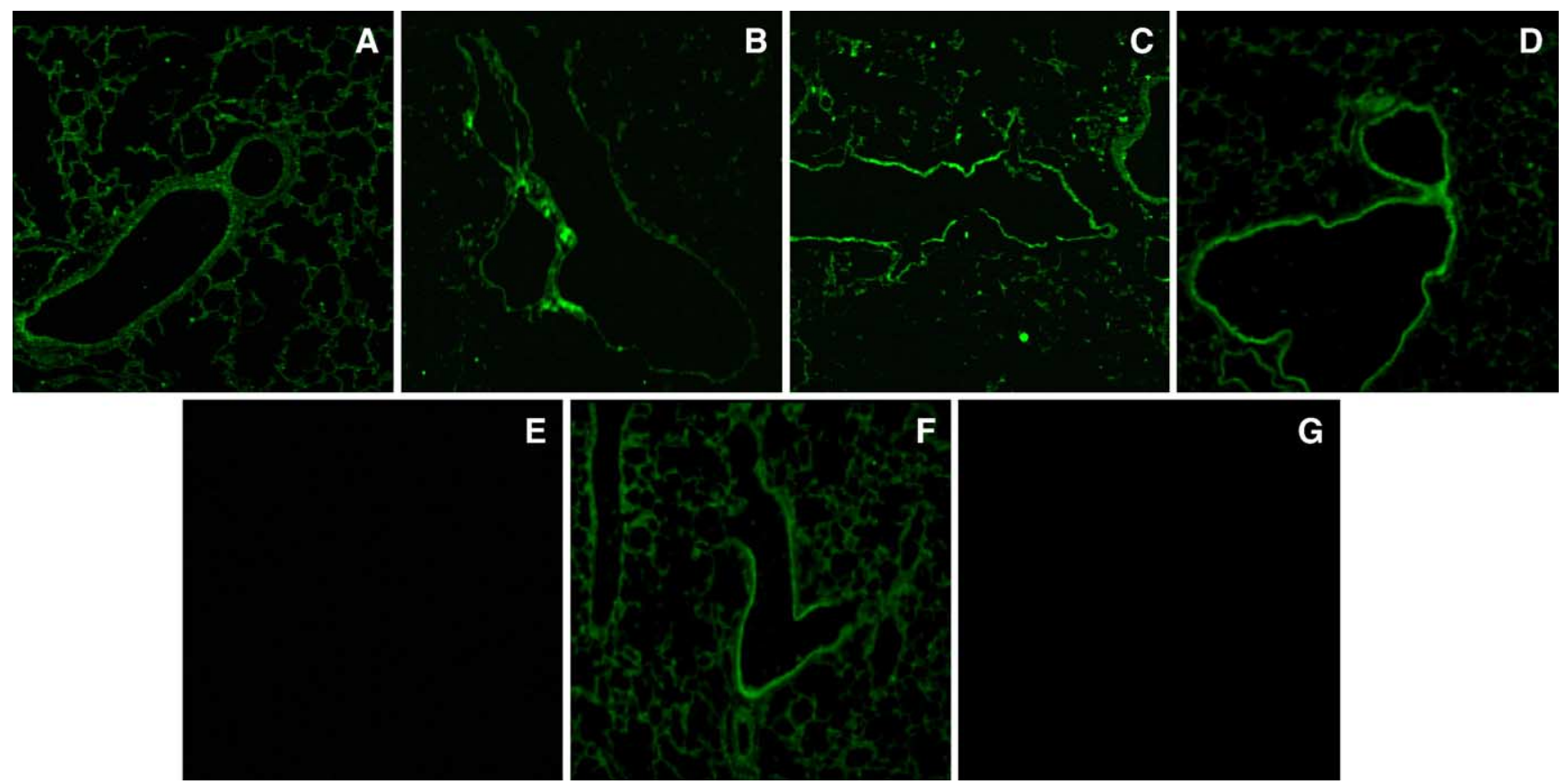

Fig. 1. Integrin characterization in mouse bronchiolar region of lung tissue sections using Alexa ${ }^{\mathrm{TM}} 488$ conjugated secondary antibody. Integrins $\alpha_{5}, \alpha_{v}, \alpha_{6}, \beta_{1}$, and $\beta_{4}$ were present in mouse small airways (A, B, C, D, and F respectively), while integrin $\beta_{3}$ was absent (E). Panel (G) shows a typical negative control, whereby the primary antibody was omitted. Magnification $\times 200$. 


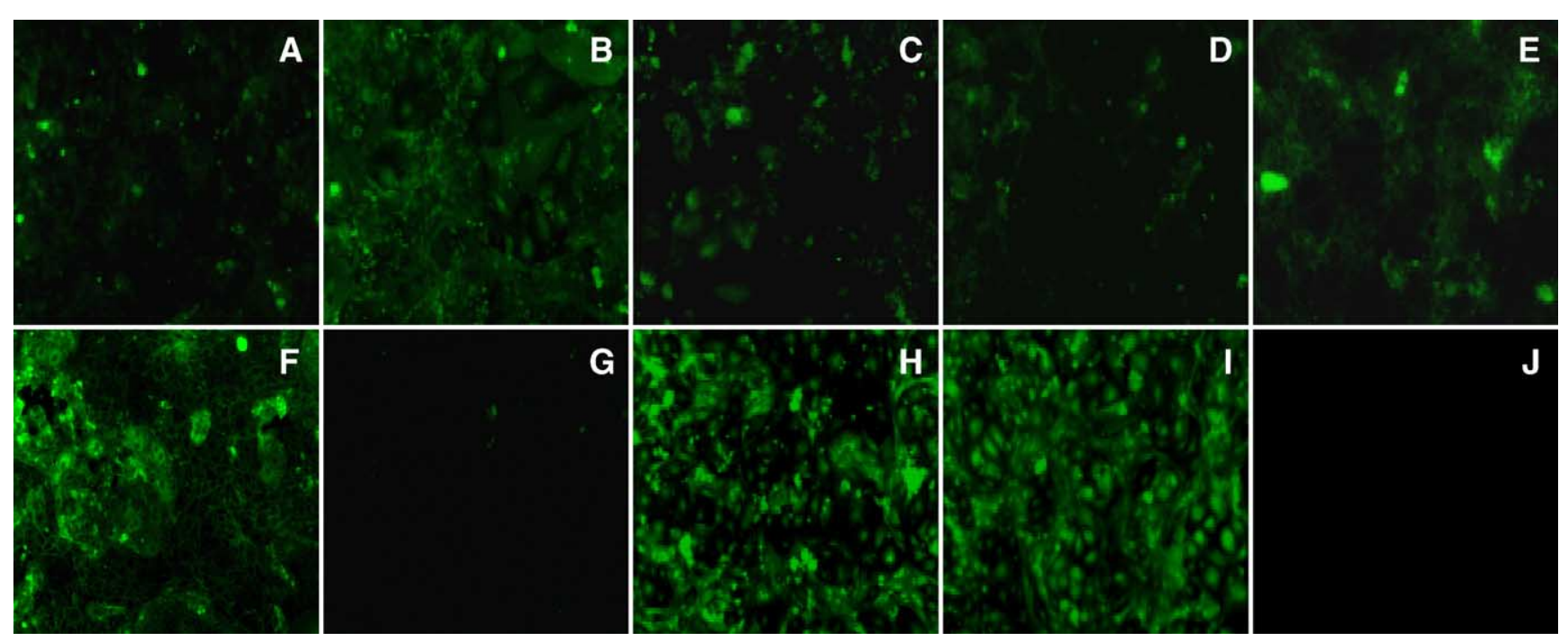

Fig. 2. Integrin characterization in Clara cell cultures using Alexa ${ }^{\mathrm{TM}} 488$ conjugated secondary antibody. An increase in the expression of $\alpha_{5}$ integrin was observed in Clara cells from $48 \mathrm{~h}$ (A) to $72 \mathrm{~h}$ (B) in culture. A decrease in the expression of $\alpha_{6}$ was observed from $24 \mathrm{~h}$ (C) to $120 \mathrm{~h}$ (D). No changes in the expression of integrins $\alpha_{v}(E), \beta_{1}(F)$, and $\beta_{4}\left(\mathrm{H}\right.$ and I). $\beta_{3}$ integrin was not expressed in primary Clara cells at all time points $(\mathrm{G})$. Panels (E, F, I, and G) are Clara cells at $120 \mathrm{~h}$ in culture; (H) Clara cells at $72 \mathrm{~h}$. Panel (J) is the negative control, whereby the primary antibody was omitted. Magnification $\times 200$.

while negatively or weakly stained cells were considered as negative. Experiments and counts were repeated at least three times, and standard deviation was calculated using Microsoft Excel. Counts of 500 cells were sufficient to achieve a stable running mean.

\section{Results}

$\alpha_{v}, \alpha_{6}, \beta_{1}$, and $\beta_{4}$ were all present in both mouse lung tissue sections and in primary Clara cell culture. The integrin $\beta_{3}$ was absent in both mouse lung tissue (Fig. 1) and primary Clara cell culture (Fig. 2). Although various modifications were carried out (as explained above), the integrin $\beta_{3}$ was still absent. The absent $\beta_{3}$ integrin in mouse lung and Clara cells could be either due to the non-reactive nature of the antibody or because integrin $\beta_{3}$ was not present. The latter hypothesis is more plausible since $\beta_{3}$ integrin is absent from the human bronchiolar region (Pilewski et al., 1997).

\section{Discussion}

Clara cells have been successfully isolated and cultured in serum free medium for up to $120 \mathrm{~h}$. Most of the cells were healthy looking Clara cells, the characteristics of which were described previously in McBride et al. (2000).

Various conditions of antigen retrieval techniques were evaluated in order for the detection to be successful. The best results were obtained when the microwave antigen retrieval method was used on methocarn fixed tissue sections. The use of microwave heating on formalin fixed tissue for integrin detection has not been successful (Cattoretti et al., 1993), with the exception of a relatively recent report (Gladson et al., 1996; Liapis and Hutton, 1997). Liapis and Hutton (1997) were still unable to detect specific immunoreactivity with several antibodies. A number of alternative buffers (Alsbeh and Battifora, 1995), varying the buffer $\mathrm{pH}$ (Grossfeld et al., 1996), or use of newly developed tissue fixatives (Muller et al., 1996) have been described. Even though the exact mechanism by which microwave heating works is still unclear (Shi et al., 1991, 1995), signal detection for many commonly used antibodies is superior compared to other methods such as autoclave or water bath (Tani and Phillips, 1995).

Six integrins were investigated $\alpha_{5}, \alpha_{v}, \alpha_{6}, \beta_{1}, \beta_{3}$, and $\beta_{4}$. $\alpha_{5}, \alpha_{\mathrm{v}}, \alpha_{6}, \beta_{1}$, and $\beta_{4}$ integrins were present in Clara cells both in tissue sections and cultures. $\beta_{3}$ integrin was found to be absent in mouse Clara cells. $\beta_{3}$ integrins have been previously described to be absent in human bronchiolar epithelium (Damjanovich et al., 1992; Pilewski et al., 1997). During the culture, there seems to be a decrease in $\alpha_{6}$ from $24 \mathrm{~h}$ to $120 \mathrm{~h}$ in culture. There was a decrease in $\alpha_{5}$ integrin expression from $24 \mathrm{~h}$ to $72 \mathrm{~h}$ in culture.

In conclusion, functional Clara cells have been isolated and cultured in serum free medium for up to $120 \mathrm{~h}$. Clara cells express $\alpha_{5}, \alpha_{v}, \alpha_{6}, \beta_{1}$, and $\beta_{4}$ integrins, but $\beta_{3}$ subunit was absent in both tissue sections and cultured cells.

\section{References}

Alsbeh, R., Battifora, H., 1995. Microwave antigen unmasking: which buffer solution should we use? Lab. Invest. 72, 948A.

Aplin, A.E., Howe, A., Alahari, S.K., Juliano, R.L., 1998. Signal transduction and signal modulation by cell adhesion receptors: the role 
of integrins, cadherins, immunoglobulins - cell adhesion molecules, and selectins. Pharmacol. Rev. 50, 197-263.

Arroyo, A.G., Taverna, D., Whittaker, C.A., Strauch, U.G., Bader, B.L., Rayburn, H., Crowley, D., Parker, C.M., Hynes, R.O., 2000. In vivo roles in integrins during leukocyte development and traffic: Insights from the analysis of mice chimeric for $\alpha_{5}, \alpha_{v}$, and $\alpha_{4}$ integrins. J. Immunol. 165, 4667-4675.

Belinksy, S.A., Lechner, J.F., Johnson, N.F., 1995. An improved method for the isolation of Type II and Clara cells from mice. In Vitro Cell Dev. Biol. 31, 361-366.

Boudreau, N.J., Jones, P.L., 1999. Extracellular matrix and integrin signalling: the shape of things to come. Biochem. J. 339, 481-488.

Brown, N.H., 2000. An integrin chicken and egg problem: which comes first, the extracelullar matrix or the cytoskeleton? Curr. Opin. Cell Biol. $12,629-633$.

Burns, J.A., Issekutz, T.B., Yagita, H., Issekutz, A.C., 2001. The $\alpha_{4} \beta_{1}$ (Very Late Antigen, (VLA)-4, CD49d/CD29) and $\alpha_{5} \beta_{1}$ (VLA-5, CD49e/CD29) integrins mediate $\beta_{2}$ (CD11/CD18) integrin-independent neutrophil recruitment to endotoxin-induced lung inflammation. J. Immunol. 166, 4644-4649.

Cattoretti, G., Pileri, S., Parravicini, C., Becker, M.H.G., Poggi, S., Bifulco, C., Key, G., D’Amato, L., Sabattini, E., Feudale, E., Reynolds, F., Gerdes, J., Rilke, R., 1993. Antigen unmasking on formalin-fixed, paraffin-embedded tissue sections. J. Pathol. 171, 83-98.

Coraux, C., Delplanque, A., Hinnrasky, J., Peault, B., Puchelle, E., Gaillard, D., 1998. Distribution of integrins during human fetal lung development. J. Histochem. Cytochem. 46, 803-810.

Damjanovich, L., Albelda, S.M., Mette, S.A., Buck, C.A., 1992. Distribution of integrin cell adhesion receptors in normal and molignant lung tissue. Am. J. Respit. Cell Mol. Biol. 6 (2), 197-206.

Dedhar, S., Hannigan, G.E., 1996. Integrin cytoplasmic interactions and bidirectional transmembrane signalling. Curr. Opin. Cell Biol. 8, $657-669$

Felding-Habermann, B., O’Toole, T.E., Smith, J., Fransvea, E., Ruggeri, Z.M., Ginsberg, M.H., Hughes, P.E., Pampori, N., Shattil, S.J., Saven, A., Mueller, B.M., 2001. Integrin activation controls metastasis in human breast cancer. Proc. Natl. Acad. Sci. U. S. A. 98, 1853-1858.

Frisch, S.M., Ruoslahti, E., 1997. Integrins and anoikis. Curr. Opin. Cell Biol. 9, 701-706

Giancotti, F.G., 1997. Integrin signalling: specificity and control of cell survival and cell cycle progression. Curr. Opin. Cell Biol. 9, 691-700.

Gladson, C.L., Hancock, S., Arnold, M.M., Faye-Patersen, O.M., Castleberry, R.P., Kelly, D.R., 1996. Stage-specific expression of integrin $\alpha_{\mathrm{v}} \beta_{3}$ in neuroblastic tumors. J. Pathol. 148, 1423-1434.

Grossfeld, G.D., Shi, S.-R., Ginsberg, D.A., Rich, K.A., Skinner, D.G., Taylor, C.R., Cote, R.J., 1996. Immunohistochemical detection of thrombospondin-1 in formalin-fixed, paraffin-embedded tissue. J. Histochem. Cytochem. 44, 761-766.

Hemler, M.E., 1998. Integrin associated proteins. Curr. Opin. Cell Biol. 10, $578-585$.

Howe, A., Aplin, A.E., Alahari, S.K., Juliano, R.L., 1998. Integrin signalling and cell growth control. Curr. Opin. Cell Biol. 10, 220-231.

Hynes, R.O., 1992. Integrins: versatility, modulation and signalling in cell adhesion. Cell 69, 11-25.
Hynes, R.O., 2000. Cell adhesion: old and new questions. Trends Cell Biol. 9, M33-M37.

Ingber, D., 1991. Integrins as mechanochemical transducers. Curr. Opin. Cell Biol. 3, 841-848.

Legier, D.F., Wiedle, G., Rose, F.P., Imhof, B.A., 2001. Superactivation of integrin $\alpha_{v} \beta_{3}$ by low antagonist concentrations. J. Cell. Sci. 114, $1545-1553$.

Liapis, H., Hutton, K., 1997. Detection of Integrins in formalin-fixed, paraffin-embedded tissues. J. Histochem. Cytochem. 45, 737-741.

Masek, L., Richards, R.J., 1990. Interactions between paraquat, endogenous lung amines' antioxidants and isolated mouse Clara cells. Toxicology 63, 315-326.

McBride, S., Tatrai, E., Blundell, R., Kovacikova, Z., Cardozo, L., Adamis, Z., Smith, T., Harrison, D., 2000. Characterisation of lectin binding patterns of mouse bronchiolar and rat alveolar epithelial cells in culture. Histochem. J. 32, 33-40.

Mizejewski, G.J., 1999. The role of integrins in cancer: survey Sof expression patterns. Proc. Soc. Exp. Biol. Med. 222, 138.

Muller, A.M., Olert, J., Cronen, C., Kirkpatrick, C.J., 1996. Detection of adhesion molecules on endothelial cells in paraffin sections. Pathol. Res. Pract. 1992, 81A.

Noto, K., Kato, K., Okumura, K., Yagita, H., 1995. Identification and functional characterization of mouse CD29 with a mAb. Int. Immunol. 7, $835-842$.

Oreffo, V.I.C., Morgan, A., Richards, R.J., 1990. Isolation of Clara cells from the mouse lung. Environ. Health Perspect. 85, 51-64.

Pilewski, J.M., Latoche, J.D., Arcasoy, S.M., Albelda, S.M., 1997. Expression of integrin cell adhesion receptors during human airway epithelial repair in vivo. Am. J. Physiol. 273, L256-L263.

Richards, R.J., Oreffo, V.I.C., Lewis, R.W., 1990. Clara cell cultures from the mouse and their reaction to bronchiolar toxins. Environ. Health Perspect. 85, 119-127.

Schwartz, M.A., 1997. Integrins, oncogenes, and anchorage independence. J. Biol. Chem. 139, 575-578.

Shi, S.-R., Key, M.E., Kalra, K.L., 1991. Antigen retrieval in formalinfixed, paraffin-embedded tissues: an enhancement method for immunohistochemical staining based on microwave oven heating of tissue section. J. Histochem. Cytochem. 39, 741-748.

Shi, S.-R., Gu, J., Kalra, K.L., Chen, T., Cote, R.J., Taylor, C.R., 1995. Antigen retrieval technique: a novel approach to immunohistochemistry on routinely processed tissue sections. Cell Vis. 2, 10-22.

Shyy, J.Y.-J., Chien, S., 1997. Role of integrins in cellular responses to mechanical stress and adhesion. Curr. Opin. Cell Biol. 9, $707-713$.

Tani, Y., Phillips, T.K.M.E., 1995. Comparison of water bath, microwave, and autoclave methods of thermal-induced target retrieval for immunohistochemical staining based on microwave oven heating of tissue sections. Lab. Invest. 72, 988A.

Van Scott, M.R., Hester, S., Boucher, R.C., 1987. Ion transport by rabbit nonciliated bronchiolar epithelial cells (Clara cells) in culture. Proc. Natl. Acad. Sci. U. S. A. 84, 5496-5500.

Van Winkle, L.S., Buckpitt, A.R., Plopper, C.G., 1996. Maintenance of differentiated murine Clara cells in microdissected airways cultures. Am. J. Respit. Cell Mol. Biol. 14, 586-598. 